\title{
Design Considerations of a Flexible Biogas Digester System for Use in Rural Communities of Developing Countries
}

\author{
Jerome Ndam Mungwe ${ }^{1 *}$, Derek Ajesam Asoh ${ }^{1,2,3}$, Edwin Mbinkar ${ }^{3}$ \\ ${ }^{1}$ Department of Electrical and Power Engineering, Higher Technical Teachers Training College, University of Bamenda, \\ Bambili, Cameroon \\ ${ }^{2}$ Department of Electrical and Electronic Engineering, National Higher Polytechnic Institute, University of Bamenda, \\ Bambili, Cameroon \\ ${ }^{3}$ Laboratoire de Genie Electrique, Mechatronique et Traitement du Signal, ENSPY, University of Yaounde I, Yaounde, Cameroon \\ Email: *mungwe.jerome@polimi.it
}

How to cite this paper: Mungwe, J.N., Asoh D.A. and Mbinkar, E. (2021) Design Considerations of a Flexible Biogas Digester System for Use in Rural Communities of Developing Countries. Journal of Sustainable Bioenergy Systems, 11, 260-271. https://doi.org/10.4236/jsbs.2021.114016

Received: October 13, 2021

Accepted: December 21, 2021

Published: December 24, 2021

Copyright (c) 2021 by author(s) and Scientific Research Publishing Inc. This work is licensed under the Creative Commons Attribution International License (CC BY 4.0).

http://creativecommons.org/licenses/by/4.0/

\section{Open Access}

\begin{abstract}
Several challenges are associated with the development, adoption and deployment of biogas digesters in developing countries. Amongst these challenges is a comprehensive and systematic procedure for the design of digesters suitable for rural communities. This paper proposes the Flexible Biogas Digester System (FBDS) as a viable option for rural communities in developing countries and provides a detailed step-by-step procedure for its design. The biogas production process is a function of the digester operating factors which may be grouped into physical, process and performance parameters. The physical design parameters include the digester volume, the volume of the biogas storage tank, and the volume of the installation pit. The process parameters include total solid content of the slurry (TS), organic loading rate (OLR), digester operating temperatures, $\mathrm{pH}$ of the slurry inside the digester. The performance parameters include biogas production rate, biogas productivity and biogas quality. The Net Present Value and the Levelised Cost of Energy are presented for simple economic evaluation of the FBDS.
\end{abstract}

\section{Keywords}

Flexible Biogas Digester System, Design Parameters, Biogas in Rural

Communities, Biogas in Sub-Sahara Africa, Digester Design Factors

\section{Introduction}

Biogas technology has been identified as a means to increase access to clean and 
modern energy carriers in developing countries, especially Sub Sahara Africa [1] [2] [3]. Several types of biogas digesters exist and have been in use in many parts of the world. Amongst the types of biogas digesters which have been developed and used worldwide, only the Nepali GGC 2045 and Chinese fixed dome have been in limited use in Sub-Saharan Africa. The limited development and use of digesters in Sub-Saharan Africa may be attributed to the many challenges associated with the development, adoption and deployment of these types of digester in rural communities of developing countries [1] [3] [4].

One major challenge associated with the development of digester is the insufficient literature on a comprehensive and systematic procedure for the design, implementation, and performance evaluation of digesters suitable for rural communities.

The objective of this paper is to fill the knowledge gap on digester design. The Flexible Biogas Digester System (FBDS), also known as the plastic digester, is proposed as a viable option for both rural and urban households in developing countries and provides a step-by-step detailed procedure on how to design the digester. The design, implementation and performance evaluation of the FBDS will help to improve access to clean and modern energy carriers through the use of renewable local resources to meet energy needs for cooking in what is termed "need-resource matching" [5].

\section{Energy Production Using the Flexible Biogas Digester System}

The energy carrier produced by the FBDS is biogas. Biogas is a renewable and clean energy carrier with a calorific value of $21-37.5 \mathrm{MJ} / \mathrm{m}^{3}$ and is made up of a composition of several gases, namely: Methane $\left(\mathrm{CH}_{4}\right)$, Carbon dioxide $\left(\mathrm{CO}_{2}\right)$, Hydrogen Sulphide $\left(\mathrm{H}_{2} \mathrm{~S}\right)$, Water vapour $\left(\mathrm{H}_{2} \mathrm{O}\right)$, Ammonia $\left(\mathrm{NH}_{3}\right)$, Carbon monoxide $(\mathrm{CO})$, Nitrogen $\left(\mathrm{N}_{2}\right)$, Oxygen $\left(\mathrm{O}_{2}\right)$ and Hydrogen $\left(\mathrm{H}_{2}\right)$ [6] [7]. It is produced from the digestion of organic waste by microorganisms via the anaerobic process. The anaerobic process is made of four stages: hydrolysis, acidogenesis, acetogenesis and methanogenesis [6] [8] [9]; with different groups of microorganism participating at each stage of the process [9]. The principle of the anaerobic process is influenced by environmental conditions, solid content of organic material used, and the type of physical technology used. Thus the process and technology may be grouped into categories [2] [10] [11] based on:

- solid content (\% TS) of influent: the digester/process could be Wet Anaerobic Digestion where the \% TS of the influent is less than $10 \%$ or Dry Anaerobic Digestion where the \% TS is greater than $10 \%$.

- operating temperatures: the digester/process may be operated under thermophilic $\left(40^{\circ} \mathrm{C}-70^{\circ} \mathrm{C}\right)$, mesophilic $\left(20^{\circ} \mathrm{C}-45^{\circ} \mathrm{C}\right)$ or psychrophilic $\left(0^{\circ} \mathrm{C}-\right.$ $20^{\circ} \mathrm{C}$ ) temperatures.

- feeding mode: the digester may be a batch, continuous, semi-continuous feed.

- mixing mode in the digester: the mixing mode of material within the digester may be plug/cross flow as in the tubular digesters, complete mix as in the 
fixed-dome and floating drum digesters, leaching bed digesters.

Various types of organic materials (waste) could be used for the production of biogas. These include cow dung, chicken manure, night-soil, pig manure, vegetable residue, kitchen waste (peelings from preparation of food), food waste (fruit, food crops), water hyacinth, fallen leaves of trees, organic municipal waste and industrial organic waste [6] [7] [12] [13] [14] [15].

\section{Design Factors}

A biogas digester is a bioreactor which is used to decompose organic materials for the production of biogas through the anaerobic process. The anaerobic process occurs in four main stages as previously described, by the action of different groups of microorganisms. The biogas production process is a function of the activities of these microorganisms. The activities of the microorganisms depend on the digester operating factors which include: digester size, temperatures, total solid content, organic loading rate, $\mathrm{pH}$ and mixing of the digester content [16] [17] [18] [19].

\section{Description of the Flexible Biogas Digester System (FBDS)}

The FBDS consists of a cylindrical digestion tank and the gas storage (herein referred to as the digester), gas outlet, a gas convey pipeline, control stop corks and a biogas burner. The digester is installed in a pit for its operation; making the pit an integral part of the FBDS. By design, the digester is a sealed tubular structure with an inlet for the introduction of organic material into the digestion tank and an outlet to expel digested organic material. The inlet is made from a $60 \mathrm{~cm}$ long PVC pipe and the outlet is made from a $40 \mathrm{~cm}$ long PVC pipe. The digestion tank, where the biogas production process takes place, makes up $75 \%$ and the gas storage makes up $25 \%$ of the total volume of the unit respectively [20]. Although, other materials may be considered for use in the design, it is recommended that the digester be made from high-density polyethylene plastic (trampoline) material to take advantage of the strength of this material. The FBDS is as shown in Figure 1.

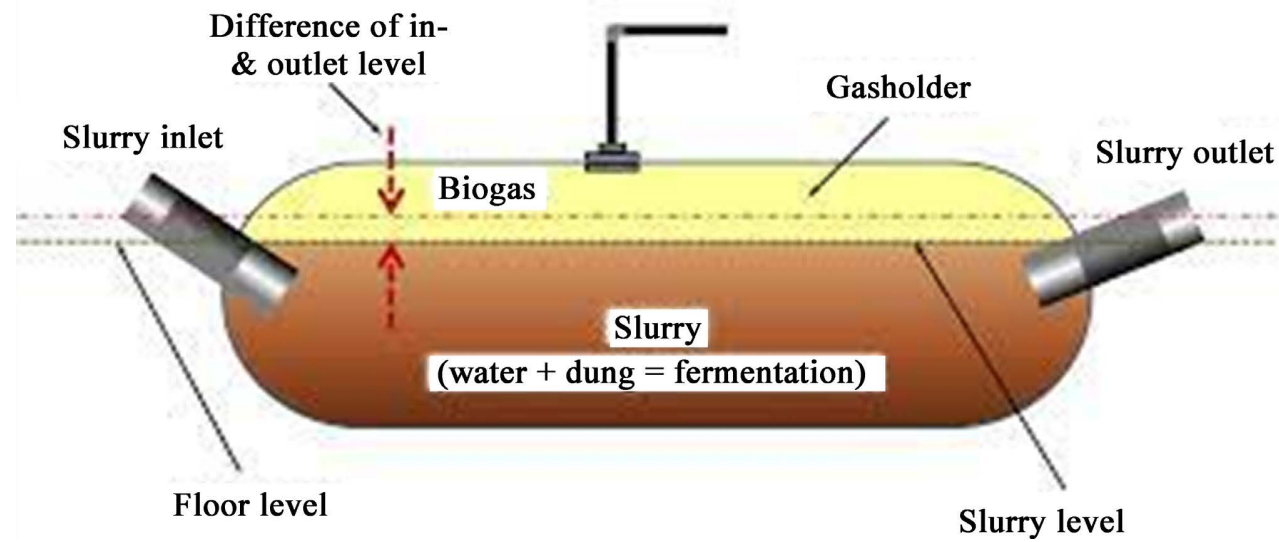

Figure 1. The flexible biogas digester system (FBDS). 


\section{Design Parameters of Flexible Biogas Digester System}

The Flexible Biogas Digester System (FBDS) comprises two main elements: the digester unit and the installation pit, in which resides the digester. In order to design and implement an FBDS, knowledge is required of the key parameters of both the digester and pit. Equally important is the necessity to match the digester size with the installation pit size for an efficient biogas production process. In this section, we present and describe the FBDS parameters for consideration during the design process. These parameters are grouped as Physical and Process Parameters. Additionally, Performance Parameters are introduced and described, which will serve as indicators of operation status of the FBDS.

\subsection{Physical Parameters}

The physical parameters which must be considered in the design of the FBDS relate to the digester with its associated elements and the installation pit. These include the volume of the digester, the volume of the biogas storage tank, the size of the inlet and outlet tubes, the volume of the installation pit, and the biogas convey pipeline. Since the digester resides in the installation pit, for practical design flexibility, the volume of the installation pit is the last design step after the digester has been designed, constructed and its various dimensions measured. The digester proposed here is a cylindrical tube. Determination of the volume of the cylindrical tube begins with determining the length of the tube from a given cross-sectional area of the tube. The volume of the digester and the biogas storage volume may be determined by one of two methods: 1) using the amount of feedstock available or 2) using the amount of energy (biogas) required daily [17] [21] [22].

Based on the amount of feedstock available, the length of the tube is determined using equations 1 to 4 . The require length of the FBDS is calculated using Equation (1) [21].

$$
\text { length }(l)=\frac{\text { total volume }\left(V_{T}\right)}{\text { cross sectional area of the tube }(A)}
$$

The total volume $\left(V_{T}\right)$ consists of the volume of the digester ( $\left.V_{d}\right)$ (liquid phase) and the gas storage (gas phase).

The liquid phase makes up $75 \%$ of the total volume and is calculated using Equation (2).

volume of liquid phase $\left(V_{l}\right)=$ volume of mixture per day $*$ retention time

where

volume of mixture $=$ quantity of fresh feedstock mixed with water in a given ratio $\left[\mathrm{m}^{3} / \mathrm{d}\right]$

volume of liquid phase $\left(\mathrm{V}_{\mathrm{l}}\right)=$ Volume of the digester $\left(\mathrm{V}_{\mathrm{d}}\right)\left[\mathrm{m}^{3}\right]$

retention time: the retention time (Equation (12)) of the slurry in the digester is determine according to the local ambient temperature.

The volume of the gas phase (gas store) make up $25 \%$ of the total volume, $V_{T}$, 
and may be calculated using Equation (3).

$$
\text { volume of gas phase (gas storage) }=V_{T}-V_{d}=25 \% V_{T}
$$

The length of the unit can now be determined from Equation (1), using Equation (4).

$$
\operatorname{volume}\left(V_{T}\right)=\pi r^{2} * \text { length }(l)
$$

Based on the quantity of energy needed the household, the volume of the digester may be determined using Equations (5) and (6). The quantity of daily biogas need of the household may be determined using Equation (5).

$$
D=n * h * b
$$

where

$\mathrm{D}\left[\mathrm{m}^{3}\right]=$ daily biogas requirement.

$\mathrm{n}=$ number of burners used in cooking

$\mathrm{h}$ [hours] = numbers of hours required for cooking

$\mathrm{b}\left[\mathrm{m}^{3}\right.$ per hour $]=$ biogas burning rate of each burner

The biogas storage is $25 \%$ of the total volume of the digester, hence the total volume may be determine using Equation (6).

$$
V_{T}=\frac{D}{25 \%}
$$

The length of the digester unit may now be calculated using Equation (4).

Dimensioning the Installation Pit

The dimensions of the installation pit are its length, width and depth, as shown in Figure 2.

Given the length of the digester as determined using Equation (4), the width of the installation pit is determined using Equation (7) [21].

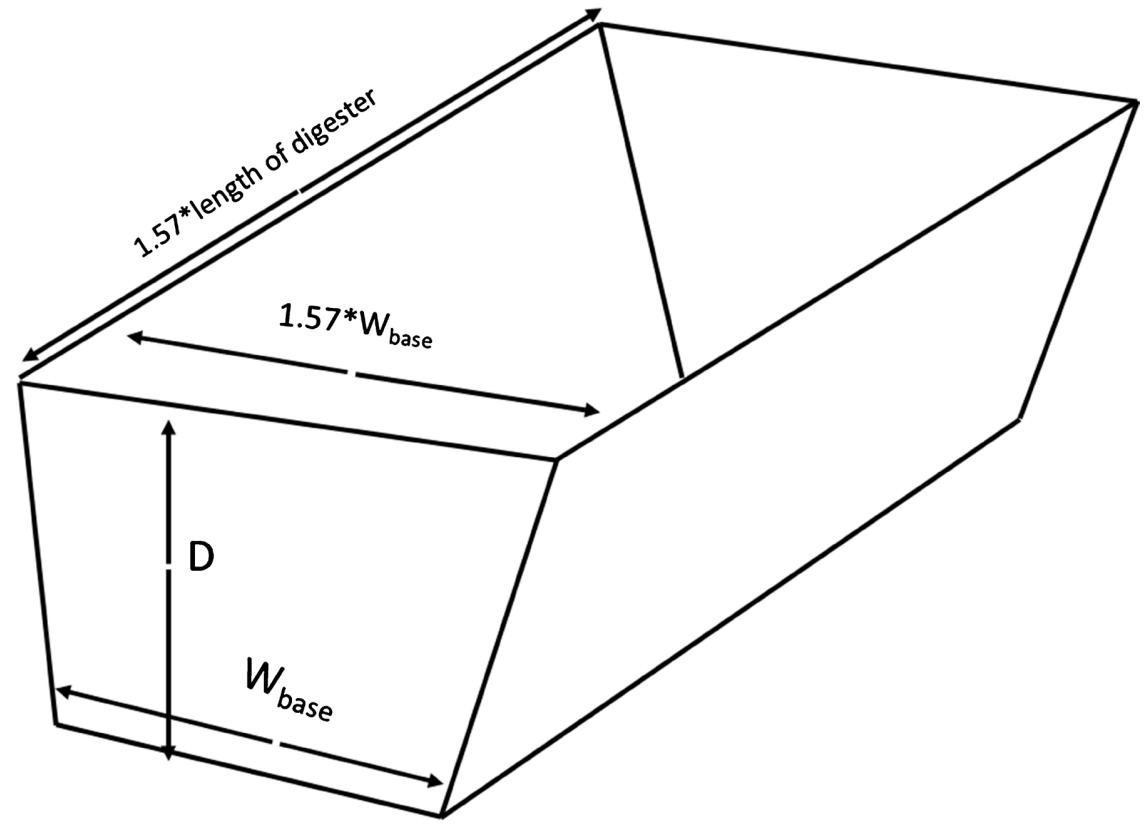

Figure 2. Dimensions of the installation pit. 


$$
W_{\text {base }}=0.9 * d
$$

where:

$\mathrm{W}_{\text {base }}=$ width of the installation pit at the base, and $\mathrm{d}=$ diameter of digester

The width at the top of the installation pit is $1.57 \mathrm{~W}$, in order to get the inclination as shown in Figure 2.

Similarly, the depth of the installation pit is determined by Equation (7) and the length of the Installation pit is determined from Equations (8a) and (8b).

$$
D=0.9 * d
$$

$\mathrm{D}=$ Depth of the installation pit, and $\mathrm{d}=$ diameter of digester

$$
L=1.04 * l
$$

$\mathrm{L}=$ Length of the installation pit, and $\mathrm{l}=$ calculated length of digester

\subsection{Operating or Process Parameters}

The parameters of the anaerobic digestion process include: total solid content of the slurry (TS), organic loading rate (OLR), digester operating temperatures, $\mathrm{pH}$ of the slurry inside the digester and mixing of the digester content. [19] [23] [24]. The process parameters which must be considered in the design of the FBDS are describe in the following sections.

\subsubsection{Total Solid Content of the Slurry (TS)}

The TS of the slurry fed daily into the digester determines whether the digester is operated in the wet or the dry regime. Usually, the tubular digester is operated in the wet regime wherein the TS is less than $10 \%$ of the influent. The TS is determined using Equation (9) [1].

$$
\mathrm{TS}=\% \mathrm{TS} * \text { mass of slurry }
$$

$\% \mathrm{TS}=$ percentage of total solid content of the feedstock

\subsubsection{Organic Loading Rate (OLR)}

The OLR is the quantity of volatile solids fed into the digester and may be measured in kilograms $(\mathrm{kg})$. In order to determine the OLR, the total solids (TS) fed into the digester must be determine alongside with the corresponding volatile solids, from Table 1. The OLR can be determined using Equation (10).

Table 1. Emperical values of \% TS and \% VS for feedstock common in rural areas.

\begin{tabular}{ccc}
\hline Feedstock & \%TS & \%VS \\
\hline Fowl dung & 25 & 85 \\
Cow dung & 22.5 & 85 \\
Pig dung & 17 & 80 \\
Goat dung & 28 & 80 \\
Garden weed & 18 & 82 \\
Sorted food waste & 33 & - \\
\hline
\end{tabular}




$$
\mathrm{OLR}=\% \mathrm{TS} * \% \mathrm{VS} * m
$$

where

$m=$ mass of feedstock fed into the digester, kilogram per day [kg/d]

$\% \mathrm{VS}=$ percentage volatile solids in the influent

The relationship between \%TS and \%VS is an empirical one, depending on the nature of material (feedstock) used for biogas production. Typical values commonly available for feedstock in rural areas are presented in Table 1 [10].

Alternatively, the OLR (in cubic meter per day) may be determine using the digester volume and the retention time using Equation (11) [25].

$$
\operatorname{OLR}\left[\frac{\mathrm{m}^{3}}{\mathrm{~d}}\right]=\frac{V_{d}}{R}
$$

where

OLR $=$ Organic Loading Rate $\left[\mathrm{m}^{3} /\right.$ day $]$

$V_{d}=$ volume of the liquid phase of the digester $\left[\mathrm{m}^{3}\right]$

$R=$ retention time [day] is the time the influent remains in the digester before it is ejected.

Hydraulic Retention Time $(R)$

The Hydraulic Retention Time is the time the influent remains the digester before it is ejected. It may be calculated using Equation (12).

$$
R=\frac{V_{d}}{Q}
$$

The design value of $R$ is such that it is at least twice the growth rate of the methanogenic bacteria in order to avoid washing them out of the digester. These bacteria are the slowest growing amongst the consortium of microorganism involve in the anaerobic process [20].

\subsubsection{Operating Temperature}

The consortium of anaerobic bacteria is affected by temperature within the digester. Different groups of bacteria survive within specific temperature range [1] [26]. The FBDS is designed to operate within the mesophilic range of temperature $\left(20^{\circ} \mathrm{C}-45^{\circ} \mathrm{C}\right)$. In order to insulate the digester from wide temperature fluctuations at low cost, the digester is placed in an excavated installation pit in the ground. Part of the digester is exposed to the ambient environment in order to receive heat. However, the digester is designed to operate at ambient temperature [20].

\subsection{4. pH Values}

The $\mathrm{pH}$ in the digester influences the methane production ability of the consortium of microorganisms involved in the anaerobic process. The optimum $\mathrm{pH}$ of the digestion process is 6.5 - 7.5. [27]. The $\mathrm{pH}$ is maintained by the type of substrate used and the operating temperature and OLR. For small-scale digesters, this parameter is often not important in the design of the digester [20]. 


\subsection{Performance Parameters}

The performance parameters of the biogas digester system include the biogas production rate, biogas productivity, biogas quality, and biodegradation rate. For application in rural communities, the quantity of biogas produced, biogas production rate and the biogas productivity are essential to evaluate the functioning of the FBDS.

To determine the quantity of biogas produced daily, under the determined local conditions, a gas flow meter is often installed in the gas convey pipeline. The reading is taken at every 12 - $\mathrm{h}$ interval, usually during the feeding of the digester.

The biogas production rate of the digester is determined using Equation (13).

$$
\text { Biogas production rate }=\frac{\text { qunatity of biogas produced }\left[\mathrm{m}_{\text {biogas }}^{3}\right]}{\text { days }[\mathrm{d}]}
$$

The productivity the digester is determined from the daily measurement of the biogas produced per day (in $\mathrm{m}^{3}$ per day) and the amount of volatile solid $\left(\mathrm{kg}_{\mathrm{vs}}\right)$ per day fed into the digester by using Equation (14).

$$
\text { Biogas productivity }=\frac{\text { biogas production rate }\left[\frac{\mathrm{m}_{\text {biogas }}^{3}}{\mathrm{~d}}\right]}{\text { Amount of volatile solids in the infleunt }\left[\mathrm{kg}_{\mathrm{vs}}\right]}
$$

\section{Economic Analysis of the Flexible Biogas Digester System}

The economic analysis of the biogas digester system aims at evaluating the economic viability of the system and to compare the system to other energy systems used by the household. Prevalent metrics for economic analysis often include: 1) Investment Cost of the system, 2) Operation and Maintenance (fixed and variable), 3) Net Present Value (NPV), 4)Pay Back Period, and 5) Levelised Cost of Energy (LCOE) [28] [29].

\subsection{Investment Costs}

The investment cost includes cost for: digester tube (PVC tarpaulin), inlet/outlet pipes, biogas delivery pipe, safety valves, biogas burner, excavation of the installation pit, initial feedstock to start the digester, system installation labour cost, and cost of other accessories [13] [21].

\subsection{Operation and Maintenance (Fixed and Variable)}

These costs are often difficult to determine especially for small scale biogas systems; and generally, often assumed to be within $2 \%$ of the Investment Cost.

\subsection{Net Present Value}

The NPV is the present discounted value of all future cashflow over the life an investment. It is used to determine the value of a business, investment, capital 
profit and anything which involve cash flows [19]. Small-scale digesters, such as the FBDS, do not often involve physical cash flows. However, savings from purchase of firewood or other energy carriers, displaced by biogas may be considered as cash flows in addition to the investment cost of installation of the FBDS. The NPV is determined using Equation (15).

$$
\mathrm{NPV}=-C+\sum_{i=1}^{l} \frac{I_{i}}{(1+r)^{i}}
$$

where

$$
\begin{aligned}
& C=\text { initial capital investment } \\
& I=\text { annual savings from use of biogas } \\
& I=\text { life span of the FBDS } \\
& r=\text { local discounting rate }
\end{aligned}
$$

\subsection{Levelised Cost of Energy (LCOE)}

The levelized cost of energy (LCOE) is often used to compare the cost of energy from the biogas system and cost of energy from other sources of energy for cooking in the household. The LCOE is determined using Equation (16).

$$
\sum_{n=1}^{N} \frac{c_{n}}{(1+d)^{n}} \div \sum_{n=1}^{N} \frac{E_{n}}{(1+d)^{n}}
$$

where

- $N$ [years] = the life span of the digester

- $C_{n}[\$]=$ the annual operation cost of the digester over (including the annuities of the investment cost and maintenance cost)

- $E_{n}[\mathrm{MWh}]=$ the projected annual energy production

- $d[\%]=$ the local discounting rate, assuming the investment of the digester was obtaining through a loan

- The annual operation and maintenance cost of the digester is often assumed to be $2 \%$ of the initial investment cost

\section{Discussions and Conclusions}

\subsection{Discussions}

The development, adoption and promotion of biogas technology to increase access to clean energy carriers in rural communities as well as urban households in developing countries could be achievable through the design of suitable digesters. The proper design and operation of the digester are important to win the confidence and trust of the users. The design considerations included both physical and process parameters. In the design of the physical parameters of the digesters the inlet and outlet have not been emphasized. They could be made from the PVC pipes of diameter $90-100 \mathrm{~mm}$. The length of the outlet should range from $60-100 \mathrm{~cm}$ while the inlet should be a bit longer by $20-30 \mathrm{~cm}$. The biogas convey pipeline is a function of the distance of the digester from the biogas consumption point (kitchen). The biogas convey pipeline should include two 
stop cork: one at the digester tank and the second at the biogas consumption point. This is to ensure safety. A pressure release valve may be included in the biogas convey pipeline to release some biogas out of the storage tank should the pressure become too high. The feedstock should be analyzed to determine its \% TS and \%VS which will aide in the design of the OLR.

\subsection{Conclusions}

The FBDS could be a suitable alternative technology for the production of biogas for use in rural communities as well as urban households in SSA. A step-by-step procedure for its design has been proposed. The design parameters which must be considered in the design of this digester include the physical, and operating or process parameters. The physical parameters relate to the digester with its associated elements and the installation pit. The physical parameters include: the volume of the digester, the volume of the biogas storage tank, the size of the inlet and outlet tubes, the volume of the installation pit, and the biogas convey pipeline. The operating or process parameters which must be considered include total solid content of the slurry (TS), organic loading rate (OLR), digester operating temperatures, and the $\mathrm{pH}$ of the slurry inside the digester. In addition to these design parameters, some performance parameters and economic analysis technique for evaluation of the digester has been presented. The essential performance parameters include the biogas production rate and biogas productivity, biogas quality in terms of the percentage content of methane. The NPV and the LCOE have been presented for the economic analysis of the digester.

The implementation and performance evaluation of this design procedure within specific local environmental conditions will be considered in the subsequent study.

\section{Acknowledgements}

The authors thank the Authorities of the University of Bamenda, ENSPY, University of Yaoundé I, Cameroon for their institutional and financial support.

\section{Conflicts of Interest}

The authors declare no conflicts of interest regarding the publication of this paper.

\section{References}

[1] Mungwe, J.N., Colombo, E., Adani, F. and Schievano, A. (2016) The Fixed Dome Digester: An Appropriate Design for the Context of Sub-Sahara Africa? Biomass and Bioenergy, 95, 35-44. https://doi.org/10.1016/j.biombioe.2016.09.007

[2] Orskov, E.R., Yongabi Anchang, K., Subedi, M. and Smith, J. (2014) Overview of Holistic Application of Biogas for Small Scale Farmers in Sub-Saharan Africa. Biomass and Bioenergy, 70, 4-16. https://doi.org/10.1016/j.biombioe.2014.02.028

[3] Mwirigi, J., et al. (2014) Socio-Economic Hurdles to Widespread Adoption of SmallScale Biogas Digesters in Sub-Saharan Africa: A Review. Biomass and Bioenergy, 70, 
17-25. https://doi.org/10.1016/j.biombioe.2014.02.018

[4] Usack, J.G., Wiratni, W. and Angenent, L.T. (2014) Improved Design of Anaerobic Digesters for Household Biogas Production in Indonesia: One Cow, One Digester, and One Hour of Cooking per Day. The Scientific World Journal, 2014, Article ID: 318054. https://doi.org/10.1155/2014/318054

[5] Mungwe, J.N., Bandiera, L., Accorona, D. and Colombo, E. (2016) Sustainable Energization of Rural Areas of Developing Countries-A Comprehensive Planning Approach. Energy Procedia, 93, 46-52. https://doi.org/10.1016/j.egypro.2016.07.148

[6] Mapelli, F. and Mungwe, J.N. (2013) Modern Energies Services for Cooking: From Improved Cook-Stoves to Domestic and Community Biogas Based Systems. In: Colombo, E., Bologna, S. and Masera, D., Eds., Renewable Energy for Unleashing Sustainable Development, Springer, Berlin, 43-74. https://doi.org/10.1007/978-3-319-00284-2_3

[7] Arthur, R., Baidoo, M.F., Brew-Hammond, A. and Bensah, E.C. (2011) Biogas Generation from Sewage in Four Public Universities in Ghana: A Solution to Potential Health Risk. Biomass and Bioenergy, 35, 3086-3093.

https://doi.org/10.1016/j.biombioe.2011.04.019

[8] Garfí, M., Martí-Herrero, J., Garwood, A. and Ferrer, I. (2016) Household Anaerobic Digesters for Biogas Production in Latin America: A Review. Renewable \& Sustainable Energy Reviews, 60, 599-614. https://doi.org/10.1016/j.rser.2016.01.071

[9] Saracevic, E., et al. (2019) Utilization of Food and Agricultural Residues for a Flexible Biogas Production: Process Stability and Effects on Needed Biogas Storage Capacities. Energies, 12, 2678. https://doi.org/10.3390/en12142678

[10] Jerome Ndam Mungwe, E.C., Adani, F. and Schievano, A. (2016) The Fixed Dome Digester: An Appropriate Design for the Context of Sub-Sahara Africa? Biomass and Bioenergy, 95, 35-44. https://doi.org/10.1016/j.biombioe.2016.09.007

[11] Li, Y., Park, S.Y. and Zhu, J. (2011) Solid-State Anaerobic Digestion for Methane Production from Organic Waste. Renewable \& Sustainable Energy Reviews, 15, 821-826. https://doi.org/10.1016/j.rser.2010.07.042

[12] Singh, G., Shamsuddin, M.R., Aqsha and Lim, S.W. (2018) Characterization of Chicken Manure from Manjung Region. IOP Conference Series: Materials Science and Engineering, 458, Article ID: 012084. https://doi.org/10.1088/1757-899X/458/1/012084

[13] Sehgal, K., Wanjihia, D. and Kembe, M. (2012) Flexi Biogas Systems: Inexpensive, Renewable Energy for Developing Countries. International Fund for Agricultural Development, Rome.

[14] Shapovalov, Y., Zhadan, S., Bochmann, G., Salyuk, A. and Nykyforov, V. (2020) Dry Anaerobic Digestion of Chicken Manure: A Review. Applied Sciences, 10, 1-24. https://doi.org/10.3390/app10217825

[15] Bicks, A.T. (2020) Investigation of Biogas Energy Yield from Local Food Waste and Integration of Biogas Digester and Baking Stove for Injera Preparation: A Case Study in the University of Gondar Student Cafeteria. Journal of Energy, 2020, Article ID: 8892279. https://doi.org/10.1155/2020/8892279

[16] Omotoso Agbede, O., Abiola Aworanti, O., Olaosebikan Ogunleye, O., Enahoro Agarry, S., Ayoola Babatunde, K. and Oluyemi Alagbe, S. (2020) Design and Fabrication of Electric Jacketed Anaerobic Digester. Journal of Petroleum \& Environmental Biotechnology, 11, Article No. 403.

[17] Obileke, K., Mamphweli, S., Meyer, E.L., Makaka, G. and Nwokolo, N. (2020) Design and Fabrication of a Plastic Biogas Digester for the Production of Biogas from Cow Dung. Journal of Energy, 2020, Article ID: 1848714. 
https://doi.org/10.1155/2020/1848714

[18] Nwankwo, C.S., Eze, J.I. and Okoyeuzu, C. (2017) Design and Fabrication of 3.60 $\mathrm{m}^{3}$ Household Plastic Bio Digester Loaded with Kitchen Waste and Cow Dung for Biogas Generation. Scientific Research and Essays, 12, 130-141.

https://doi.org/10.5897/SRE2017.6516

[19] Chowdhury, T.H. (2021) Technical-Economical Analysis of Anaerobic Digestion Process to Produce Clean Energy. Energy Reports, 7, 247-253. https://doi.org/10.1016/j.egyr.2020.12.024

[20] Kinyua, M.N., Rowse, L.E. and Ergas, S.J. (2016) Review of Small-Scale Tubular Anaerobic Digesters Treating Livestock Waste in the Developing World. Renewable and Sustainable Energy Reviews, 58, 896-910.

https://doi.org/10.1016/j.rser.2015.12.324

[21] Ortega, M. (2009) Installation of a Low Cost Polyethylene Biodigester. http://scholar.google.com/scholar?hl=en\&btnG=Search\&q=intitle:Installation+of+a + Low+Cost+Polyethylene+Biodigester\#2

[22] Hamid, R.G. and Blanchard, R.E. (2018) An Assessment of Biogas as a Domestic Energy Source in Rural Kenya: Developing a Sustainable Business Model. Renewable Energy, 121, 368-376. https://doi.org/10.1016/j.renene.2018.01.032

[23] Ghiandelli, M. (2017) Development and Implementation of Small-Scale Biogas Balloon Biodigester in Bali, Indonesia. KTH School of Industrial Engineering and Management, Stockholm.

[24] Gausi, E., Mlatho, S.P. and Mikeka, C. (2020) A Low-Cost Tubular Biogas Digester for Rural Households in Malawi. Malawi Journal of Science and Technology, 12, 18-42. https://www.ajol.info/index.php/mjst/article/view/201904

[25] Richardson, M.M. and Sharp, K.V. (2019) Community-Level Resource Development and Management, Part 2: A Transferable Approach to Feasibility Analysis for Biogas as an Alternative Cooking Fuel. Journal of Humanitarian Engineering, 7, 1-23. https://doi.org/10.36479/jhe.v7i1.132

[26] Naik, L., Gebreegziabher, Z., Tumwesige, V., Balana, B., Mwirigi, J. and Austin, G. (2014) Factors Determining the Stability and Productivity of Small Scale Anaerobic Digesters. Biomass and Bioenergy, 70, 51-57. https://doi.org/10.1016/j.biombioe.2014.01.055

[27] Vögeli, Y., Riu, C., Gallardo, A., Diener, S. and Zurbrügg, C. (2014) Anaerobic Digestion of Biowaste in Developing Countries.

[28] Walekhwa, P.N., Lars, D. and Mugisha, J. (2014) Economic Viability of Biogas Energy Production from Family-Sized Digesters in Uganda. Biomass and Bioenergy, 70, 26-39. https://doi.org/10.1016/j.biombioe.2014.03.008

[29] Lai, C.S., et al. (2017) Levelized Cost of Electricity for Photovoltaic/Biogas Power Plant Hybrid System with Electrical Energy Storage Degradation Costs. Energy Conver sion and Management, 153, 34-47. https://doi.org/10.1016/j.enconman.2017.09.076 